\title{
Thermochronologic constraints on the Late Cenozoic exhumation along the Alpine and West Carpathian margins of the Pannonian basin
}

\author{
I. Dunkl ${ }^{1,2}$ and W. Frisch ${ }^{1}$ \\ ${ }^{1}$ Institute of Geology, University of Tübingen, Sigwartstrasse 10, Tübingen, D-72076, Germany \\ ${ }^{2}$ Laboratory for Geochemical Research, Hungarian Academy of Sciences, Budaörsi ú 45, Budapest, H-1112, Hungary
}

Received: 1 May 2000 - Accepted: 16 July 2001

\begin{abstract}
The uplifted and partly re-exhumed basement of the Neogene Pannonian basin was investigated by the apatite fission track thermochronometer along the marginal belt to the Eastern Alps and the Western Carpathians. In some zones the reset Late Miocene apatite FT ages and the high organic maturation of the Neogene sediments give evidences on the high magnitude of the post-Middle Miocene sediment removal. Thermal modeling of the fission track data allows to quantify this removal and to conclude that its magnitude in the investigated sites was in the range of $1-1.5 \mathrm{~km}$. In this paper we review the thermochronologic data and integrate them with the seismic, structural and sedimentological evidences on the Late Miocene-Pliocene erosional phases.
\end{abstract}

\section{Introduction}

Although the Pannonian basin is mentioned as a type example for basins formed by continental rifting in many textbooks and syntheses, e.g. in the Pannonian Memoir of Royden and Horváth (1988), it actually represents an inverted basin (Horváth and Cloething, 1996). Evidences support this, like the lack of actual sediment accumulation in a significant part of the basin system. The Cenozoic sediments are under erosion in considerable areas and the hilly landscape is as typical as the alluvial plains within the basin frame. The digital elevation model of the Pannonian basin clearly shows that the basin sediments are under erosion at the northern and western margins, nearly in the whole Transdanubia and in the entire Transylvanian basin (Fig. 1). Isolated, deeply eroded sediment remnants of Miocene age are found in elevated positions in the Alps close to their eastern termination and also on the karstic plateau of the Bükk mountains in the innermost Western Carpathians. These occurrences

Correspondence to: I. Dunkl

(istvan.dunkl@uni-tuebingen.de) prove the much broader extent of the sedimentary cover in Miocene time. The elevation of these sediment remnants exceed $800 \mathrm{~m}$ a.s.l. reflecting young faulting with significant vertical displacement (Tari, 1988). This fault generation was also found in the internal part of the Pannonian basin (Csontos, 1995; Tari et al., 1999). The inversion is a widespread phenomenon and the young flank uplift of the basin system was also reported from the eastern margin in the Apuseni mountains and along the Eastern and Southern Carpathians (Sanders, 1998; Bojar et al., 1998; Willingshofer, 1999).

The aim of this paper is to evaluate the post-Middle Miocene uplift of the crystalline foot-hills of the Alps and Western Carpathians, using apatite fission track (FT) analysis and combining this information with structural data.

\section{Late Miocene and Pliocene tectonics of Eastern Alps}

The post-collisional tectonic evolution of the western Pannonian basin and its frame in the Eastern Alps and Western Carpathians is dominated by large-scale extension as a response to Eocene-Oligocene collision, nappe stacking and crustal thickening, as well as continuing plate convergence (e.g. Ratschbacher et al., 1991; Frisch et al., 1998). A steep gradient in topography and crustal thickness towards the Intra-Carpathian basin characterized the Eastern Alpine and Western Carpathian chains. The Intra-Carpathian basin (the present Pannonian basin) experienced substantial E-W extension in Early and Middle Miocene times, due to its back-arc position above the retreating subduction zone and continued N-S convergence (Royden et al, 1982).

The extension, a combination of gravitational collapse and escape of tectonic blocks ("lateral tectonic extrusion"; e.g. Ratschbacher et al., 1991), affected the Eastern Alps and the Western Carpathians as well as the present basement of the Pannonian basin. Its main expressions are horstgraben structures (mainly in the basement of the Pannonian basin), 


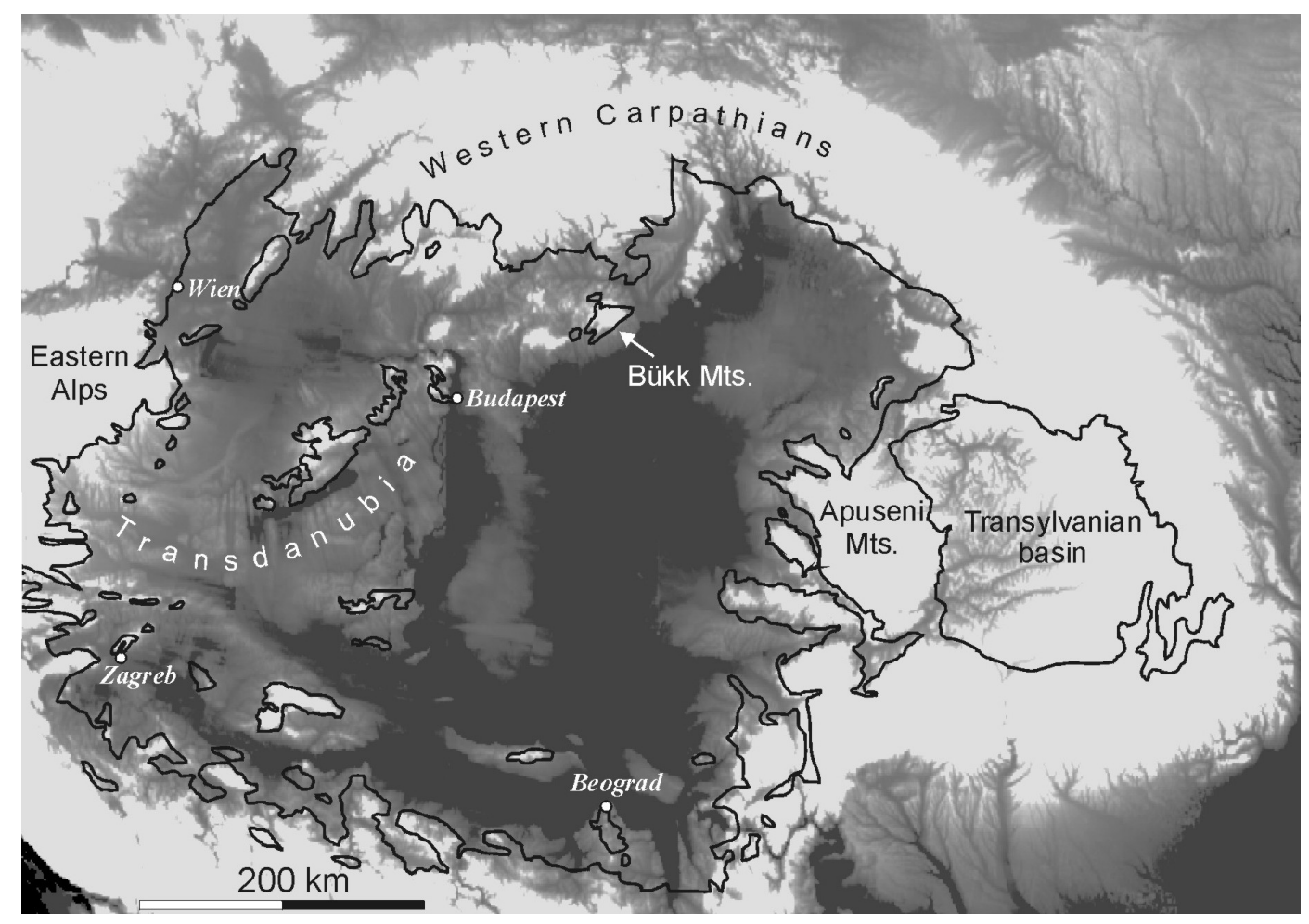

Fig. 1. Digital elevation model of the Pannonian basin displaying elevation between 100 and $400 \mathrm{~m}$ a.s.l. by grey scale, all higher areas are white. Black line: contour of the Tertiary formations of the Pannonian basin system (DEM from GLOBE, 1999; contour line from "Carte Tectonique Internationale de L'Europe et des Régions Avoisinantes”, Scale 1:25000 000, Acad. Sci. USSR, 1981).

a conjugate strike-slip fault pattern, the formation of faultbounded sedimentary basins, subduction-related volcanism, and a number of topographic features (Szabó et al., 1992; Frisch et al., 1998; Székely et al., in this volume). Sedimentation was characterized by lateral spreading from localized basins to a largely coherent sediment sheet drowning the extensional features (Sachsenhofer, 1992; Sachsenhofer et al., 1997).

According to paleomagnetic results, large parts of the Eastern Alps east of the Tauern window, the Inner Western Carpathians, and the northwestern part of the Pannonian basin carried out counterclockwise rotations up to $90^{\circ}$ during and after the main period of lateral tectonic extrusion (Márton et al., 2000). Lateral tectonic extrusion was terminated around $13 \mathrm{Ma}$ (Badenian/Sarmatian boundary; Tari et al., 1992; Dunkl and Demény, 1997; Dunkl et al., 1998). Fault plane analyses from the eastern Eastern Alps revealed a complex story for the master faults of the extrusion pattern in the post-rift period (Neubauer et al., 2000). Some of these faults are presently active and generally show the same sense of motion as during the lateral extrusion period (see below). However, Peresson and Decker (1997) and Reinecker and Lenhard (1999) showed that, after the extrusion period, E-W compression (combined with N-S extension) inverted motion along the conjugate fault pattern. Peresson and Decker (1997) constrained the period of inversion to the Late Miocene stage and related it to soft collision in the East- ern Carpathians and stress transmission across the area of the Pannonian basin. The Pannonian basin, in turn, showed considerable post-rift subsidence (Tari et al., 1992). Peresson and Decker (1997) related this process to stress-induced downward flexure of the loaded lithosphere.

The basin-scale inversion of the Pannonian basin system happened in two compressional phases: in Late Miocene and in Pliocene (Horváth, 1995). Seismic profiles often show folded or tilted Late Miocene reflectors (e.g. Vida et al., 1998), and the structural manifestations of this tectonics is even observed in the outcrop scale in the Vienna basin (Fodor, 1995; Peresson and Decker, 1997). Faulting affected the Quaternary deposits as it was detected by high-resolution seismics by Tóth and Horváth (1999) along the rivers Danube and Tisza. The formation of Lake Balaton is also related to the young compression which created its depression (Sacchi et al., 1999). Thus, although the elevations of the surrounding hills are not significant, we can call it an intramontane basin. Horváth and Cloething (1996) have considered the onset of the late stage compression to be latest Pliocene and Quaternary, Sacchi et al. (1999) proposed the very beginning of Pliocene. Recent stress measurements suggest a general compressional state of the Pannonian basin and the AlpineCarpathian neighbourhood (Bada et al., 1998; Gerner at al., 1999).

The inversion process probably led to general surface uplift in the Eastern Alps, which is manifested by increased 
erosion in the orogenic body (Kuhlemann, 2000). This is in line with at least $300 \mathrm{~m}$ of regional surface uplift established for Miocene sediment terrains in the area of the AlpineCarpathian junction (Decker, 1996). In the Styrian basin, the western annex of the Pannonian basin, Ebner and Sachsenhofer (1991) related erosion of several hundred metres of Miocene sediment in Pliocene times to basin inversion. According to Peresson and Decker (1997), at this time the E-W compressional regime already gave way to renewed N(NW)$\mathrm{S}(\mathrm{SE})$ compression.

\section{Fission track age pattern of the Eastern Alps and Western Carpathians}

The fission track method was already considered in the seventies as a powerful technique to detect the low temperature evolution of exhuming metamorphic units (Fleischer et al., 1975). Using apatite we can get information on the cooling history in the temperature range of 60 to $130^{\circ} \mathrm{C}$. This mild thermal overprint has no effect on the "classical" isotopic systems, like $\mathrm{U} / \mathrm{Pb}, \mathrm{Rb} / \mathrm{Sr}, \mathrm{K} / \mathrm{Ar}$. Another advantage of this method is that the track annealing is sensitive only to the temperature and mineral chemistry, while for example in KAr chronology the argon diffusion is also controlled by the mineral size/domain size, chemistry, fluid activity, deformation and chemical transformations (see e.g. Villa, 1998).

In their pioneering work, Wagner et al. (1977) described the cooling history of several major Alpine crystalline masses by apatite FT data measured along vertical profiles. This initiated a "boom" in the apatite FT studies in the Alps, so that they became the best investigated orogen in this respect (see, e.g. the compilation of Hunziker et al., 1992). The authors of this paper compiled 293 apatite FT ages from the Eastern Alps. Several of these ages (54) are unpublished measurements of the Budapest, Tübingen and Bochum fission track laboratories. The published data are from Staufenberg (1987), Hejl and Wagner (1989), Neubauer et al. (1995), Hejl (1997), Fügenschuh et al. (1997), Dunkl and Demény (1997), Sachsenhofer et al. (1998), Dunkl et al. (1998), Reinecker (1999), Grasemann and Dunkl (submitted).

\subsection{Eastern Alps}

Before reviewing the apatite data we have to look over the high-temperature chronometers of the orogen. The K/Ar, $\mathrm{Ar} / \mathrm{Ar}$ and $\mathrm{Rb} / \mathrm{Sr}$ results measured on micas outlined the two main Alpine thermotectonic phases of the Eastern Alps: a Late Cretaceous one and a Miocene one (see compilation of Frank et al., 1987; Genser et al., 1996 and Dallmeyer et al., 1996). The exhumation of metamorphic rocks of greenschist and amphibolite facies during late Cretaceous times set the mica chronometers in the great part of the Austroalpine nappe system between 100 and $70 \mathrm{Ma}$. There are also some islands of non-overprinted zones, where pre-Alpine ages have been preserved (see Frey et al., 1999; Neubauer et al., 1999). The largest areas of very low-grade and low-grade
Cretaceous overprint are found in the Silvretta-Ötztal Alps, Gurktal Alps and in the Wechsel region, where the typical mica ages are Variscan (Müller et al., 1999; Neubauer et al., 1999). The Penninic metamorphic rocks of the Tauern and Rechnitz windows show mainly Neogene mica cooling ages (Frank et al., 1987; Genser et al., 1996).

The density of apatite FT ages allows to draw a map which is an updated and interpreted version of the work set about by Hejl and Wagner (1991). For the compilation of such an areal projection of a 3D data set, we have to consider also the elevation of the dated samples. The vertical extent of the partial annealing zone (ca. $60-130^{\circ} \mathrm{C}$ ) of apatite ages is similar to the recent relief of the Eastern Alps (ca. $3 \mathrm{~km}$ ), thus along subvertical profiles the apparent ages can be rather different (Staufenberg, 1987). This is why we set rather long age bins in the compilation map, and for the boundaries of the age bins we have also considered the ages of the known events of the Alpine evolution (see Fig. 2).

The present day apatite FT age pattern of the Austroalpine areas in the Eastern Alps is a result of the superposition of the effect of Neogene exhumation and re-heating on the inherited, Late Cretaceous-Paleogene ages (Fig. 2). There are zones in the Austroalpine realm, where the Neogene denudation is negligible or considerably less than the depth of the apatite partial annealing zone. In these blocks (a great part of the Gurktal Alps, Koralpe, Sopron Mts.) the apparent ages are Paleogene, in places as old as $62 \mathrm{Ma}$ (Hejl, 1997, 1999; Grasemann and Dunkl, submitted). Apatite FT ages younger than $20 \mathrm{Ma}$ occur mainly within the Penninic Windows (Grundmann and Morteani, 1995; Staufenberg, 1987; Dunkl and Demény, 1997) where they mark the low-temperature cooling after the tectonic denudation. In the Austroalpine areas such young ages are located along fault zones (Mölltal, Periadriatic lineament), and at around the frames of the Penninic windows, where resetting of the apatite ages was caused by increased heat flow due to tectonic denudation. Miocene ages also mark intensely exhuming areas like the Niedere Tauern (Hejl, 1997; Reinecker, 1999). The burial heating of the former Miocene sedimentary cover resulted in Neogene FT ages by total reset in the crystalline basement of the Pohorje mountains, in the Rechnitz window and in parts of the Wechsel structure. We emphasize that these occurrences are situated at the margins of the Pannonian basin.

\subsection{Western Carpathians}

$\mathrm{K}-\mathrm{Ar}$ and ${ }^{40} \mathrm{Ar} /{ }^{39} \mathrm{Ar}$ white mica and biotite ages from the Western Carpathians constrain the Cretaceous tectonic overprint within greenschist and locally amphibolite facies conditions and the subsequent Late Cretaceous cooling through appropriate closure temperatures of these minerals (ca. 85$80 \mathrm{Ma}$ ) (Maluski et al., 1993; Dallmeyer et al., 1996).

There are much less apatite fission track data available in the Western Carpathians than in the Alps, only Burchart (1972), Král' (1977) and Árkai et al. (1995) have published FT results. The ages mark a northward younging trend. The 


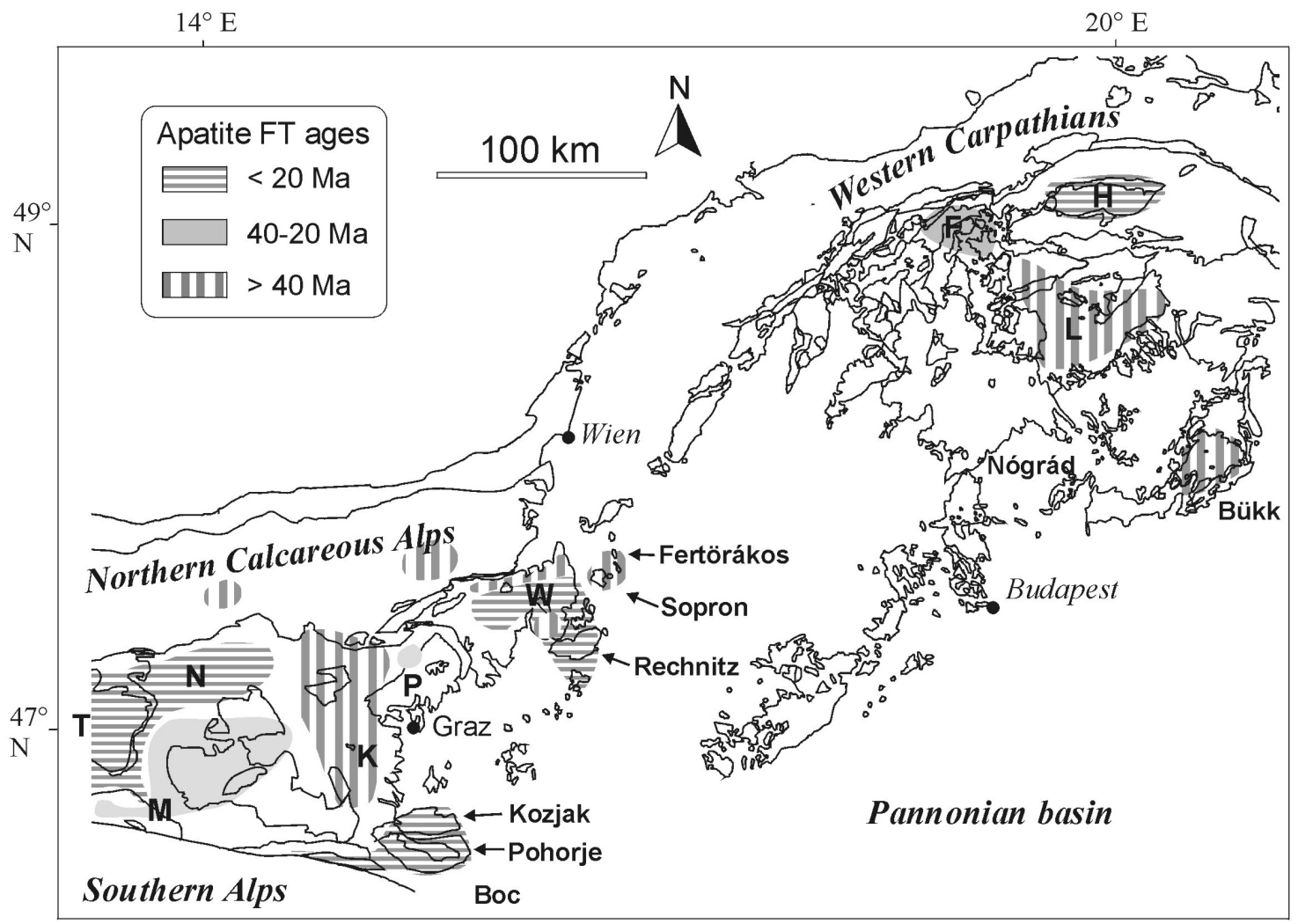

Fig. 2. Areal distribution of apatite fission track ages of the Eastern Alps and Western Carpathians. As there are areas of pronounced vertical shift of ages the characteristic values were chosen that are representing the ages between 1000 and $1500 \mathrm{~m}$ elevation in the high mountains. Main units: T: Tauern window, N: Niedere Tauern, M: Mölltal, W: Wechsel structure, P: Paleozoic of Graz, K: Koralpe, H: High Tatra, L: Low Tatra, F: Fatra Mts. The references of the data are in the text. Map contours are after Fuchs (1985).

Inner Western Carpathians (Bükk and Lower Tatras) have apatite ages between 89 and $40 \mathrm{Ma}$; the Fatra Mts. show FT data of Early Miocene age and the outermost crystalline block, the High Tatra Mts., has ages between 15 and $10 \mathrm{Ma}$ (Fig. 2).

\section{A brief methodology}

Unfortunately, the above presented data set has a limited value. These ages are partly rather old and express post-metamorphic cooling below $\sim 100^{\circ} \mathrm{C}$ during Late Cretaceous-Paleogene time. The Neogene FT ages are also not too informative for the latest period and a great part of them is situated far away from the Pannonian basin: around the Tauern structure and in the Outer Western Carpathians (High Tatra). The majority of the ages in the compilation presented above are only apparent ages, without confined track length measurements. Why has the track length distribution a special role in the interpretation of the apatite FT ages? Wagner (1979) classified the mechanism of the formation of FT ages into three main groups (Fig. 3). The "formation ages" are expressing the age of a volcanic rock, when the cooling rate is very high and no track annealing takes place after the formation of a lava or ash layer. The "slow cooling" mecha- nism is typical for intrusive and metamorphic bodies, where the final exhumation may succeed the thermal climax after a long time span. In this case the meaning of the apparent age is approached by the closure temperature concept (Dodson, 1973). The "mixed ages" are formed when a rock body spent relative long time in the partial annealing zone, either by stagnation during exhumation or due to the mild thermal effect of a burial period. These ages can not be related to a given event. The meaning of such mixed ages can be revealed by the analysis of the track lengths. Shortening of fission tracks was first observed by Bigazzi (1967), the systematic research of this phenomenon has started in the eighties (Laslett et al., 1987). Studies of natural annealing sites and sequences of laboratory experiments were used to reveal the time/temperature dependence of track shortening in apatite. The etchable length of the unshortened tracks is around $15 \mu \mathrm{m}$, this is the typical value for fast cooling rocks with formation ages (Fig. 3). By progress of thermal annealing, the mean value becomes shorter and the length distribution gives a mirror on the thermal history.

Several annealing kinetics have been presented (Laslett et al., 1987; Carlson, 1990; Crowley et al., 1991; Donelick et al., 1999), which are used in computer modeling procedures in order to reveal the thermal history. Usually forward mod- 


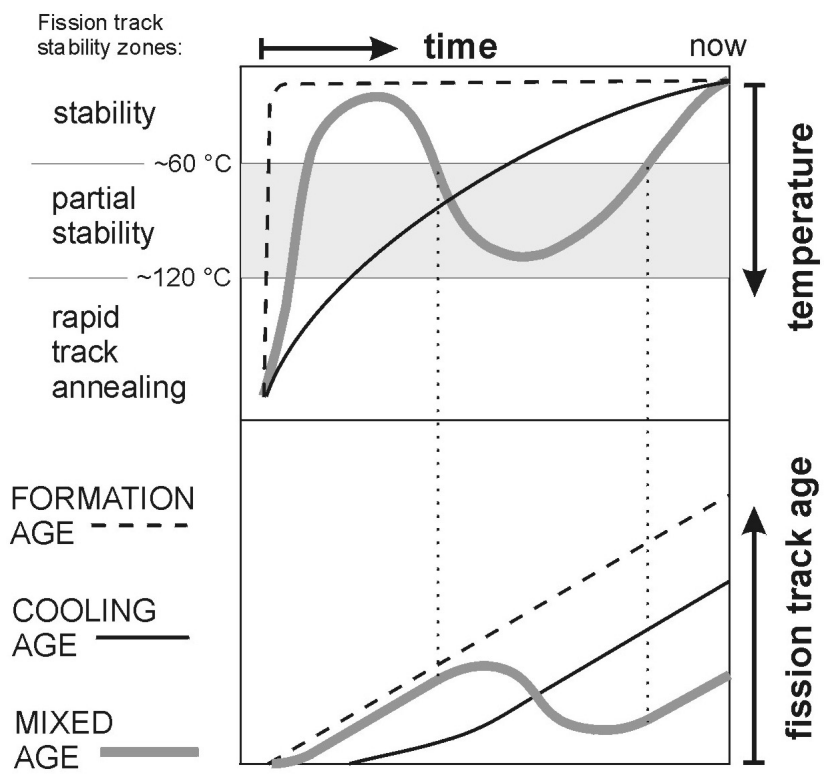

Fig. 3. The three main classes of fission track ages, after Wagner (1979). Our case studies (sediment burial with mild thermal overprint) result mainly in mixed ages.

eling is used to create synthetic apparent FT ages and track length distributions from a supposed time/temperature path (Willet, 1992; Gallagher, 1993; Ketcham et al., 2000). Statistical tests give numeric values to evaluate the reliability of the supposed thermal path. Repeated calculations can yield several acceptable time/temperature (tT) paths, which form a belt in a graphical presentation and which we will call a "tTenvelope" below. Using length measurements and this kind of computer calculations, the rather limited meaning of the simple apparent ages formed by "slow cooling" or "complex cooling" can be extended and the FT data can tell a thermal history (Gleadow et al., 1983). In our studies, we used the Laslett's annealing kinetics for modeling, and in cases, in which the chemical composition of the dated apatite grains (chlorine-fluorine substitution) was measured by electron microprobe, the Donelick's kinetics was considered. Both the MonteTrax and the AftSolve computer programs were used (Gallagher, 1993; Ketcham et al., 2000).

In many cases there are only two points available in the tT space: the age and temperature of the last metamorphic event, and the point representing the recent situation $(0 \mathrm{Ma}$ and the annual mean temperature). The low numbers of parameters of the FT data allows to create rather broad tTenvelopes, by other words, several alternatives exist and different tT paths result in very similar track annealing (Fig. 4a). If the history of the vertical movements is complex and if, after the last metamorphism, the crystalline rocks were buried by a sedimentary pile, we can fix additional point(s) on the tT plot. These can be the beginning of sedimentation, beginning of sediment removal, age of maximum burial and the maximum temperature deduced from organic maturation in the sediments. Using these constraints as fix points, thermal modeling gives much narrower tT-envelopes than in the case
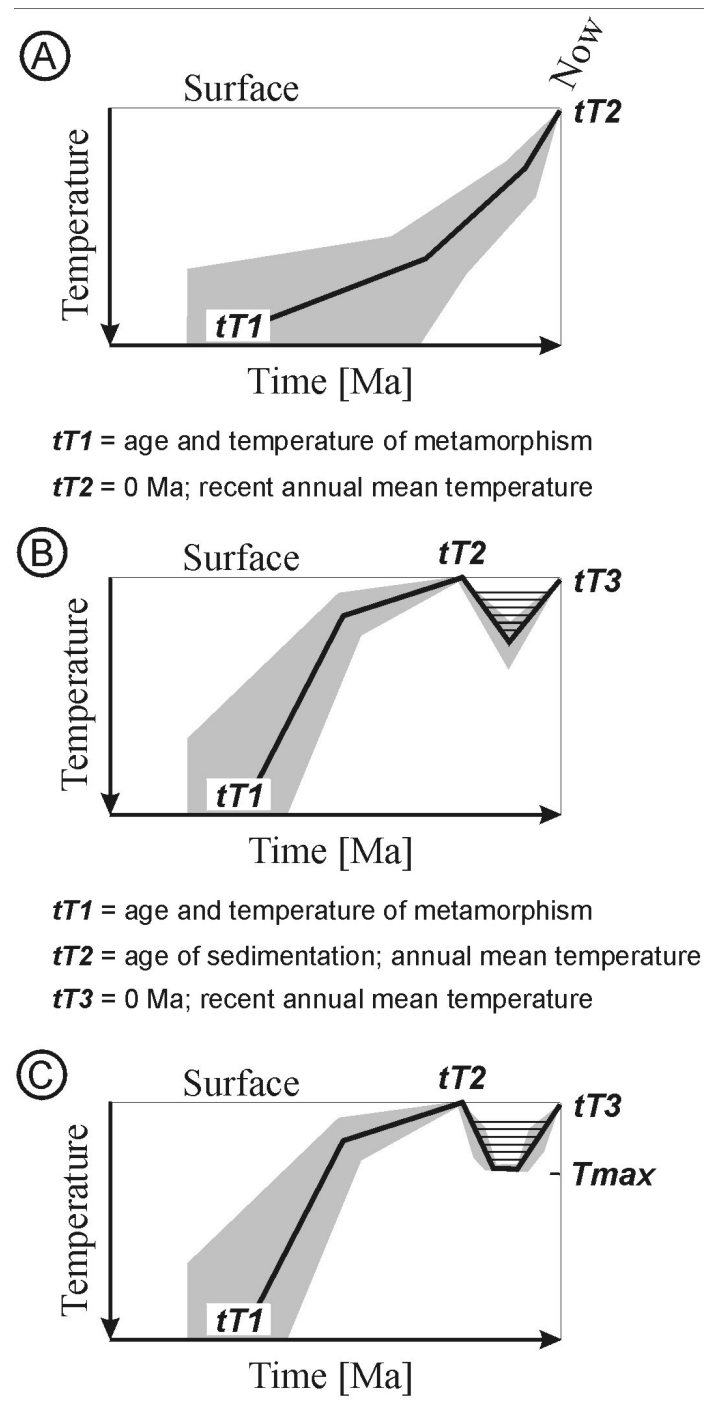

$T$ max $=$ maximum temperature during burial

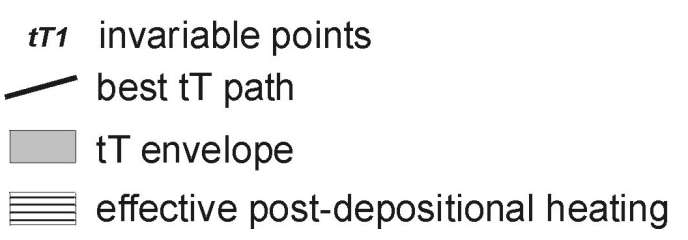

Fig. 4. Schematic cartoons presenting (a) the thermal modeling of the cooling of a metamorphic rock, when no additional knowledge exists on the trend of exhumation. The tT (time-temperature) envelope covering the acceptable thermal paths can be rather broad due to the few constraints. In case when one can insert the age of sedimentation (b) as an additional invariable point and when the organic maturation gives a limit for the maximum of the post-depositional temperature (c) the duration of the final effective heating can be estimated more precisely.

of the two-point-modelings. Especially important in the survey of young thermal events is that by fixing the tT point of sedimentation we get good temperature constraints for the burial temperature of the latest period (Fig. 4b). If the maximum temperature is also known the timing of the burial tem- 
perature becomes even more constrained (Fig. 4c).

It is common in all studies presented below, that they concern such a geologic situation, in which crystalline rocks were buried by Neogene sedimentary sequences and later this cover was partially or fully removed by erosion. In all cases field observation and/or seismic profiles give evidence of young uplift and sometimes the increased vitrinite reflectance proves the high burial temperature. The fission track results are mainly mixed ages formed by the shorter or longer stay in the partial annealing zone (see Fig. 3). By thermal modeling of FT data we made an approach to date and quantify the paleo-burial. The most dubious point of these calculations is the conversion of the maximum temperature to maximum burial or the tT-envelope to burial history. Here we reach the problematics of the paleo-geothermal gradient. The Early Miocene extension and subsidence, which produced depressions for sediment accumulation was accompanied by an extreme increase of the heat flow (Ebner and Sachsenhofer, 1995). The syn-rift volcanism (Szabó et al., 1992; Sachsenhofer et al., 1997) resulted also in numerous local anomalies. The paleo-heat flow can be estimated, when a vertical profile of the indicators of thermal overprint is preserved in the Neogene sediments. Such vitrinite reflectance profiles can be measured in the central parts of the subbasins like in the Styrian basin (Ebner and Sachsenhofer, 1995). However, in our research area along the exhumed margin of the Pannonian basin, the sediment remnants are generally thin and the determination of vertical trends is impossible. Thus, in some cases we had to apply the heat flow history on the exhumed basal sequences, which was determined on the central part of the (sub)basins. It may introduce some error into the calculations. The trend of cessation of the heat flow and the age of erosion is also not exactly known, but the apatite fission track chronometer could fix the age of final cooling in some cases of the following studies.

\section{Uplift estimates along the western and northern mar- gin of the Pannonian basin}

5.1 Pohorje and Kozjak mountains and the Boc area, Slovenia

\subsubsection{Geology}

The crystalline core of these mountains is composed of Austroalpine metamorphic rocks and Oligocene intrusives. At the slopes, Miocene sediments are onlapping and form erosional remnants (Jelen et al., 1992). Vitrinite reflectance of the Middle Miocene sediments exposed at the surface have values of up to Ro $=2.5 \%$ (Sachsenhofer et el., 1998). These data indicate a strong thermal overprint and also infer sedimentary burial, since the thermal blanketing of the sediment cover is necessary to locally exceed the temperature of $\sim 150^{\circ} \mathrm{C}$ (Sachsenhofer et al., 1998). The basin remnants are dissected (Fodor et al., 1998, 1999), the depths of Late- and
Post-Miocene erosion probably vary between the structural slabs.

\subsubsection{Fission track data}

Total post-depositional reset can be found in some zones of the Neogene sequence, the apparent apatite ages are around 13.7 Ma and 11.8 Ma in the Pohorje and Boc regions, respectively (Sachsenhofer et al., 2001). The track length distributions indicate minor shortening, thus the FT ages can be interpreted as the result of relatively rapid cooling in latest Badenian-Sarmatian time. The ages are in excellent agreement with the modeled heat flow history of Sachsenhofer (1994) and the known age of the cessation of the extensional movements in the western Pannonian sub-basins recorded by seismic studies (Tari et al., 1992). The unreset sediments contain apatite grains usually 2-3 Ma older than the age of sedimentation, which indicates an intense exhumation process in the immediate vicinity of the basin in Early-Middle Miocene time.

\subsubsection{Calculated burial history}

Deep Neogene sediment burial of the Pohorje and Kozjak region is evident from the vitrinite data and from the reset of the apatite FT clock. Estimation of the burial depth is mainly controlled by the assumed heat flow history. The calculation is based on the measured thermal conductivity of the Neogene sediments (Dövényi and Horváth, 1988). The presence of syn-rift volcanic formations and the vertical profile of the vitrinite reflectance values indicate an increased Middle Miocene heat flow. Ebner and Sachsenhofer (1995) and Sachsenhofer (1994) have calculated heat flow values of $>300 \mathrm{~mW} / \mathrm{m}^{2}$ in the surrounding of the stratovolcanoes and a general increase to the range of $100-150 \mathrm{~mW} / \mathrm{m}^{2}$ for the central part of the Styrian basin. Using these figures, the syn- and post-rift burial of the recently exhumed Slovenian basement highs is calculated to be around $1000-1500 \mathrm{~m}$.

\subsection{Surroundings of the Rechnitz window}

\subsubsection{Geology}

In the Rechnitz window Penninic metasedimentary units are exposed which underwent Tertiary metamorphism. During tectonic denudation (Early to Middle Miocene, Dunkl and Demény, 1997), the hanging wall formed an extensional allochthon with very rugged surface. Boulders in the conglomerate sequences and the strongly undulating relief of the basement of Neogene basin fill are proof of intense normal faulting (Pahr, 1984; Ratschbacher et al., 1990). The organic maturation of the Neogene sequences proves a thermal overprint, the vitrinite values in some parts of the syn-rift sediments are as high as Ro $=1.04 \%$ (Sachsenhofer, 1991). 

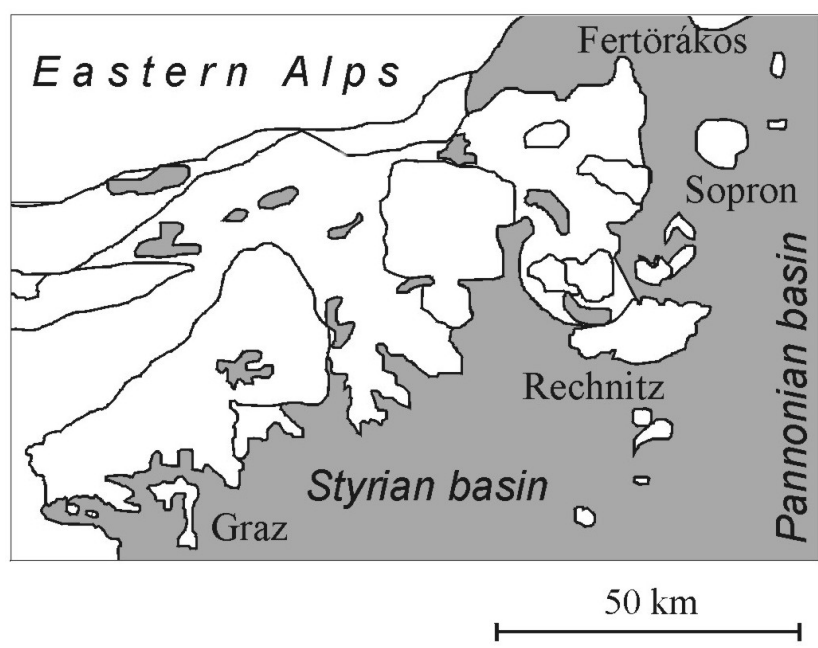

Fig. 5. Isolated Miocene basin remnants in the mountainous area of the Eastern Alps. The geology of the Alpine units has no importance in this respect, thus all of them are white. Contours after Flügel and Neubauer (1984).

\subsubsection{Fission track data}

Unfortunately, the Penninic mafic rocks are rather poor in uranium, thus, precise apatite FT dating is impossible. Samples of few tracks yield ages around $10 \mathrm{Ma}$. The reset Miocene sedimentary samples gave an average apatite age of 13.6 $\pm 0.9 \mathrm{Ma}$ (Dunkl et al., 1998). Confined track length distributions indicate fast cooling at around $12 \mathrm{Ma}$ and that later the temperature of the base of the Miocene sedimentary sequence was lower than the thermal range of track annealing (Grasemann and Dunkl, submitted). It is remarkable that this age is rather close to the apparent ages of the reset samples around the Pohorje-Kozjak Mountains (see above; Sachsenhofer et al., 1998). The main reason of the temperature drop is the cessation of the high, extension-related heat flow. However, the beginning of the denudation is also already possible at that time as Horváth (1995) has reported noticeable intra-basinal erosion in the Pannonian realm (11$9 \mathrm{Ma})$.

\subsubsection{Calculated burial history}

The total reset of the apatite FT ages and the high vitrinite reflectance values prove that the post-Early Miocene burial temperature at the bottom of several sub-basins exceeded $\sim 120^{\circ} \mathrm{C}$. At the margin of the Rechnitz window, advection of the rising hot Penninic footwall increased the heat flow in the hanging wall. The heat flow reached the range of 140$150 \mathrm{~mW} / \mathrm{m}^{2}$ in the immediate vicinity of the window (Dunkl et al., 1998). The calculated maximum burial was between 1.1 and $1.6 \mathrm{~km}$ in the rifting period. However, these figures are valid only for a relatively small area. The extrapolation of these modeled values to a broader region of the Rechnitz window is problematic, since both the heat flow (Grasemann and Dunkl, submitted) and the depth of the basin formed along the extensional structure were rather irregular (Flügel, 1988).

\subsection{Sopron Mountains}

\subsubsection{Geology}

These localities are belonging to the easternmost, islandlike exposures of the Austroalpine nappe pile, composed of metamorphic rocks of greenschist and amphibolite facies (Lelkes-Felvári et al., 1983). The partly eroded Middle Miocene sedimentary cover consists of coarse conglomerate, coal seams and shallow marine carbonates. Unfortunately, there are no published data on the grade of organic maturation. The depth of the Neogene basin is strongly irregular; in a distance of $8 \mathrm{~km}$ - between the crystalline islands - the thickness of the molasse sediments may change from 0 to $1500 \mathrm{~m}$ (Fülöp, 1990). This variation is the result of Late Miocene normal faulting which is also responsible for the exhumation of the crystalline basement in the island hills. A $\sim 40^{\circ}$ rotation of the paleomagnetic declinations of the Pannonian strata ( $8 \mathrm{Ma}$ ) gives further evidence for intense Late Miocene-Pliocene tectonics (E. Márton, written comm., 1999). The regional scale of the exhumation and the much broader extent of the Neogene sediments in former times is obvious, if we consider the distribution of the intramontane basin remnants in the surroundings (Fig. 5).

\subsubsection{Fission track data}

The apatite apparent FT ages range between 40 and $60 \mathrm{Ma}$ (Dunkl, 1992), and the confined track length distributions show relatively minor bulk shortening and small standard deviation (mean: $14.0 \pm 1.0 \mu \mathrm{m}-500$ tracks). The lack of strongly shortened tracks refers the rapid cooling during $\mathrm{Pa}$ leogene times and the long stay of the recently exposed rocks in the track stability zone $\left(<50^{\circ} \mathrm{C}\right)$. However, the overall shortening indicates some young thermal overprint.

\subsubsection{Calculated burial history}

The total reset of the apatite FT ages and the high coal rank as it was observed in the surroundings of the Slovenian crystalline hills and the Rechnitz window are missing around Sopron. In this zone, the Neogene molasse was sedimented on a passively behaving basement, no rifting and volcanic activity is known from this region. The apparent ages and the track length distribution mirror a longer time period than the Late Neogene burial; a part of the shortened tracks was already formed in the Early Tertiary. This is the reason that the effect of the Late Neogene burial heating cannot be extracted so exactly as in case of the samples which underwent Miocene total resetting. Thermal modeling of the FT data shows mild re-heating with peak temperatures around $60^{\circ} \mathrm{C}$. There is no indication to suppose a strongly increased geothermal gradient, thus a value of $50^{\circ} \mathrm{C} / \mathrm{km}$ was used for the burial estimation. The value of $41.6^{\circ} \mathrm{C} / \mathrm{km}$ applied by Dövényi and Horváth (1988) is rather expressing the recent thermal state 


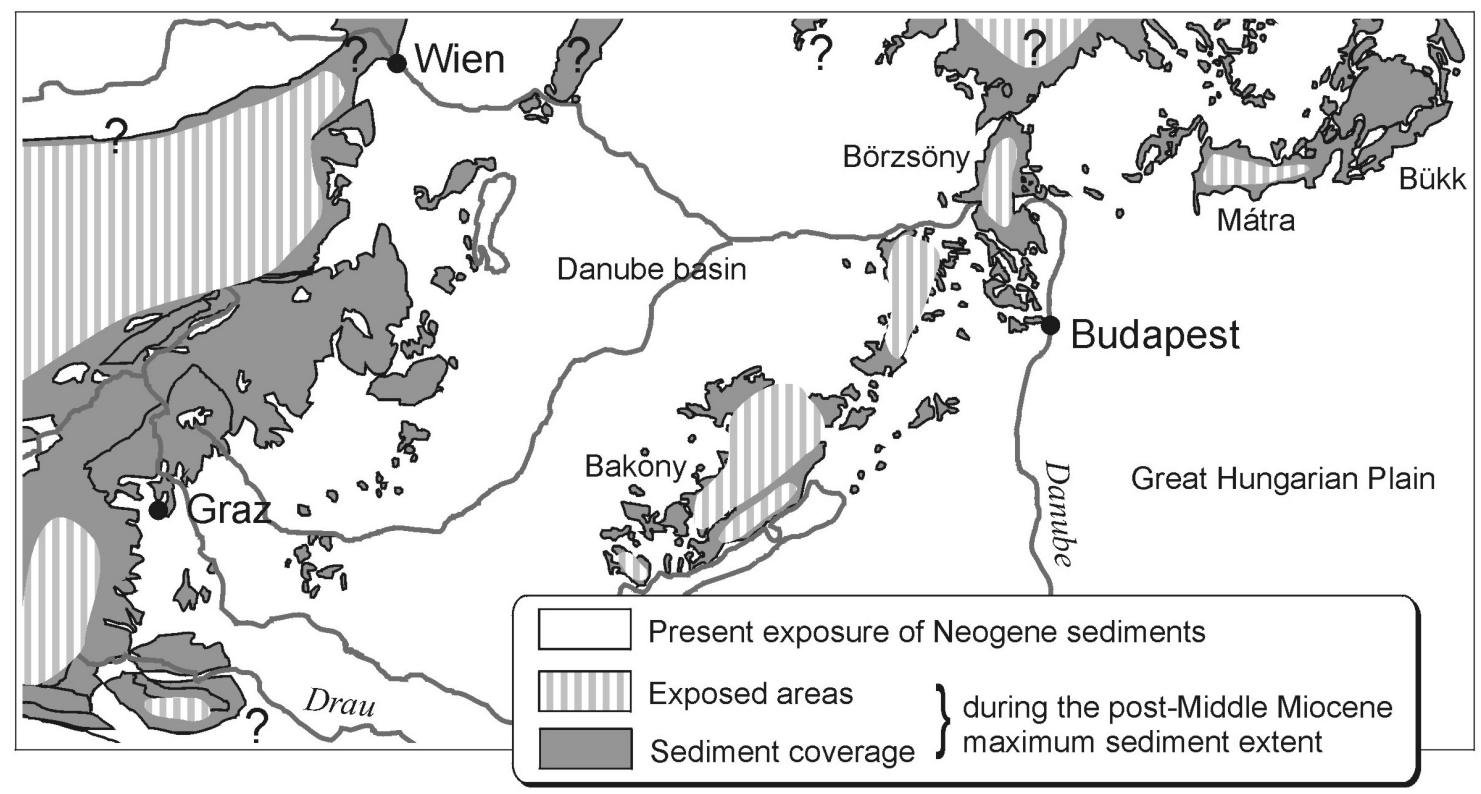

Fig. 6. Supposed maximum extent of Neogene sedimentary cover along the western and northern margin of the Pannonian basin.

of the Danube basin, east of our site, where Neogene extension is pronounced and subsidence was even active in Quaternary times. The estimated value of $\sim 1 \mathrm{~km}$ for the maximum burial is in harmony with the thickness of the sedimentary remnants in the non-uplifted small basins and sedimentary embayments around Sopron (Fülöp, 1990).

\subsection{Fertörákos hills}

These hills are situated in the immediate vicinity of the Sopron Mts. and the geological situation and the geochronological data show a similar picture (Frank et al., 1996). The major difference between the Sopron and Fertörákos crystalline basement is that they represent different levels within the Austroalpine nappe pile (Frank et al., 1986). The quality of the FT data are similar to those of the Sopron Mts., but one factor causes a bit more complication: some of the samples were derived from a depth of $720 \mathrm{~m}$ from the borehole Fr-1004. Thus, the calculation of the paleo-burial is additionally biased by the different conductivity of the crystalline and the slightly consolidated sedimentary rocks. The estimated paleo-burial is around $1 \mathrm{~km}$.

\subsection{Nógrád region}

\subsubsection{Geology}

The crystalline basement of the Vepor unit is covered by a 500-2000 m thick Oligo-Miocene sedimentary sequence. At the investigated site (Szécsény) the actual burial is $800 \mathrm{~m}$. The region is under intense denudation, the hill slopes are steep and landslides are typical for this area. The erosion exposes different levels of the molasse sequence (Csiky, 1968).

\subsubsection{Fission track data}

The dated crystalline samples derived from the base of the sedimentary fill and yield $\sim 46 \mathrm{Ma}$ apparent apatite ages (Dunkl, 1993). The overall track shortening is very pronounced (mean: $12.0 \pm 1.4 \mu \mathrm{m}-60$ tracks). The recent temperature of $42^{\circ} \mathrm{C}$ is not sufficient to create such track shortening. Therefore, it is obvious that the temperature of the top of the basement significantly exceeded the present value during Late Miocene-Pliocene times.

\subsubsection{Calculated burial history}

The most contrasting fact of this geological situation to the Alpine foothills is that the age of the cover sediments is slightly older here, i.e. Egerien ( $25 \mathrm{Ma})$. Thermal modeling gives a good fit to the observed figures when the Miocene burial temperature is in the range of $75-90^{\circ} \mathrm{C}$ and cooling started not earlier than $5 \mathrm{Ma}$ ago. For the conversion of the temperature data to depth, we have to consider that the region was penetrated by andesite dikes during Middle Miocene time. However, Horváth et al. (1986) have proved that the thermal effect of these thin dikes is very local, and therefore they probably did not significantly increase the geothermal gradient of the whole region. For the estimation of the maximum burial we can take the recent geothermal gradient of the region. Dövényi and Horváth (1988) determined $54.6^{\circ} \mathrm{C} / \mathrm{km}$ for the area immediately south of our site, the map of Stegena (1979) indicates a value of $47^{\circ} \mathrm{C} / \mathrm{km}$. The paleo-burial calculations result in ranges between $1-1.2 \mathrm{~km}$ and $1.1-1.3 \mathrm{~km}$, respectively. These figures seem reliable as they are similar to the thickness of the missing upper part of the molasse sequence. 


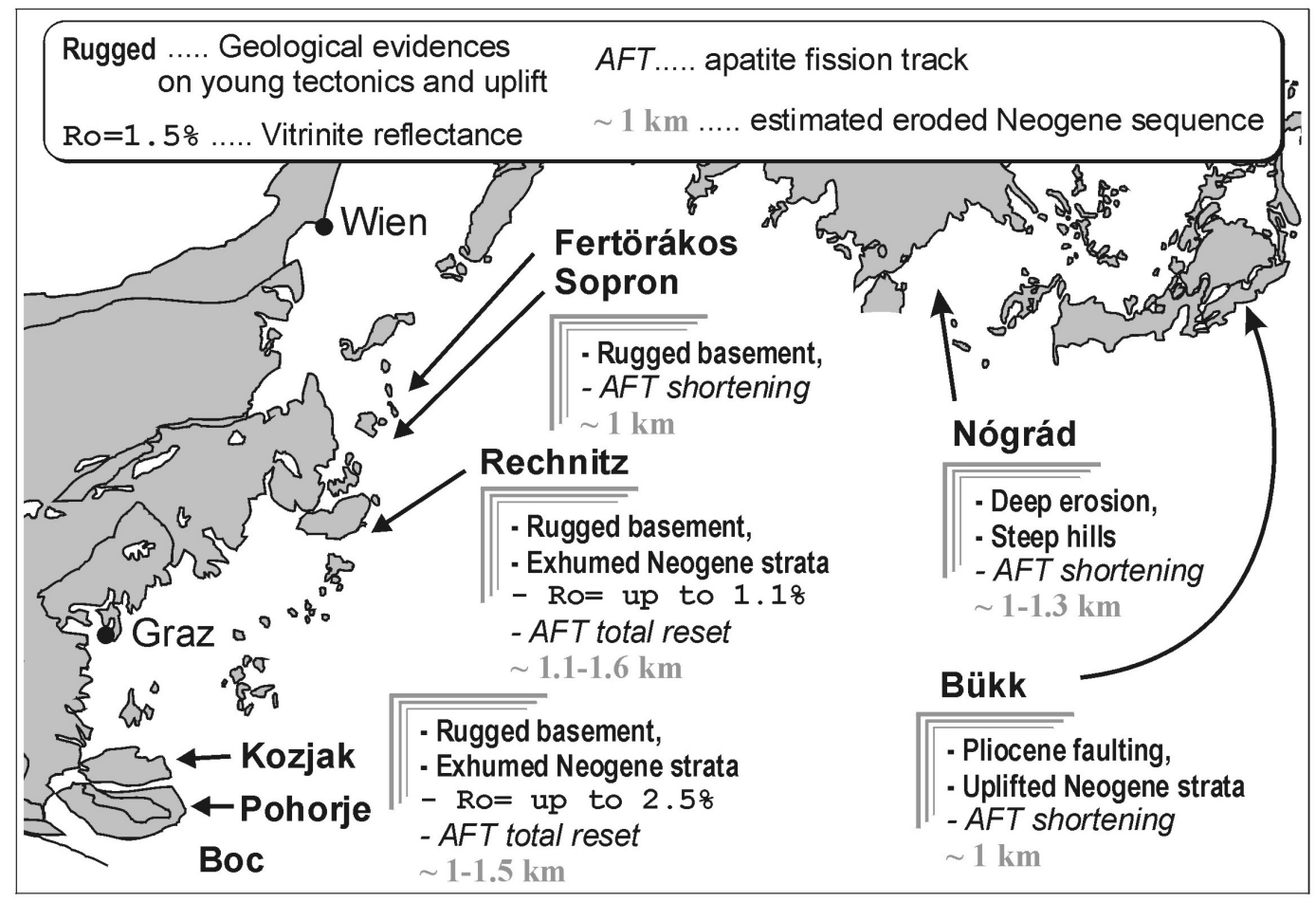

Fig. 7. Compilation of the erosion-relevant observations and the estimated post-Middle Miocene sediment removal. Gray areas: Pre-Tertiary basement and Neogene volcanics.

\subsection{Bükk Mountains}

\subsubsection{Geology}

The low-grade metamorphic Paleozoic rocks of the Bükk Mountains (Árkai, 1991) were exhumed to the surface during the Paleogene, and the marine Eocene cover sediments indicate its first burial. Perfect biostratigraphical and sedimentological data record this event (reviewed in Dunkl et al., 1994). Then Miocene sedimentation covered the basement which is deeply eroded today. The karstic plateau of the Bükk mountains has an elevation of $\sim 800 \mathrm{~m}$ a.s.l., and seismic studies prove that the great part of this uplift happened in Pliocene-Quaternary times (Tari, 1988).

\subsubsection{Fission track data}

The apparent apatite ages range between 32 and $65 \mathrm{Ma}$ depending on the structural unit, chemical composition and elevation of the samples (Árkai et al., 1995). Track length distributions show mild overall shortening.

\subsubsection{Calculated burial history}

Due to the precise Tertiary stratigraphy and sedimentological control around the exhumed plateau it was possible to consider several independent information for the timing of the burial periods. The latest, Miocene burial was rather mild and caused only slight track shortening. In the calculation of the burial depth we can consider a rather cool geothermal sit- uation above the buried Paleozoic and Mesozoic rocks. Thus, the estimated Late Miocene burial was around $1 \mathrm{~km}$.

\section{Discussion and conclusions}

Fission track thermochronology and modeling of the raw data yield valuable information on the latest thermal overprint on the crystalline marginal hills of the western Pannonian basin. The results on the quantification of the postEarly Miocene burial are in harmony with the stratigraphic and structural data. An important paleo-geographic consequence can be drawn from the burial data: the extent of the Neogene sediments of the Pannonian basin was much wider during Middle and Late Miocene times than suggested by the present-day exposures. A belt of at least $40 \mathrm{~km}$ in width of removed sediments can be considered along the western margin. Beyond the burial of the Pohorje-Kozjak, Rechnitz and Sopron-Fertörákos regions, we suppose that the Koralpe, the Paleozoic of Graz and the entire Wechsel region were also under molasse coverage (Fig. 6). According to the Late Miocene facies pattern and morphological observations the central parts of the Bakony, Börzsöny and Mátra mountains formed islands (Pécsi, 1991; Báldi-Beke et al., 1980; Jámbor, 1980; and pers. comm. D. Karátson, 2001), while the entire Bükk was under sediment coverage. The red clay, some badly dated gravel occurrences and the planation surfaces (Nock paleosurface, Exner, 1949) also indicate that a 
part of the Eastern Alps further to the west was also covered by sediments (Thiedig, 1970).

The following conclusions can be drawn from the thermochronologic and structural data:

- The Pliocene-Quaternary compressional tectonics has a lot of surface manifestations. The major part of the western Pannonian basin is inverted, and presently the Neogene sediments are under denudation in big areas.

- Isolated sediment remnants of Miocene age both in the Eastern Alps and in the Inner Western Carpathians prove the former broader extent of the sedimentary cover.

- Thermal modeling of apatite fission track data from selected sites on top of the basement at the immediate contact to the covering and partly eroded Neogene sediments yield essential information on the thermal history of the latest burial period. The integrated annealing effects of burial heating allows to conclude that paleoburial during Middle-Late Miocene and Pliocene times was in the range of $1-1.5 \mathrm{~km}$ in the recently exhumed foothills of the Eastern Alps and the Western Carpathians (Fig. 7).

Acknowledgements. B. Székely (Tübingen/Budapest) has computed the digital elevation model presented in Fig. 1. F. Neubauer (Salzburg) and two anonymous reviewers have reviewed the manuscript and gave valuable advices. E. Márton and D. Karátson (Budapest) have informed us on unpublished paleomagnetic results and geomorphologic observations. Their help is gratefully acknowledged. The German Science Foundation financed the compilation of this study in the frame of the Collaborative Research Centre 275.

\section{References}

Árkai, P.: Chlorite crystallinity: an empirical approach and correlation with illite crystallinity, coal rank and mineral facies as exemplified by Paleozoic and Mesozoic rocks of northeast Hungary, J. Metamorph. Geol., 9, 723-734, 1991.

Árkai, P., Balogh, K., and Dunkl, I.: Timing of low-temperature metamorphism and cooling of the Paleozoic and Mesozoic formations of the Bükkium, innermost Western Carpathians, Hungary, Geol. Rundschau, 84, 334-344, 1995.

Bigazzi, G.: Length of fission tracks and age of muscovite samples, Earth Planet. Sci. Lett., 3, 434-438, 1967.

Bada, G., Cloetingh, S. A. P. L., Gerner, P., and Horváth, F.: Sources of recent tectonic stress in the Pannonian region: inferences from finite element modelling, Geophys. J. Int., 134, 87-102, 1998.

Báldi-Beke, M., Bohn-Havas, M., Korecz-Laky, I., Nagy-Gellai, Á., and Nagy, E.: Recent paleontolological and stratigraphical results on the Oligocene and Miocene of the Bözsöny Mountains and its surroundings, Discuss. Palaeontol., 26, 61-103, 1980.

Bojar, A.-V., Neubauer, F., and Fritz, H.: Cretaceous to Cenozoic thermal evolution of the southwestern South Carpathians: evidence from fission-track thermochronology, Tectonophysics, 297, 229-249, 1998.

Burchart, J.: Fission track age determinations of accessory apatite from the Tatra Mountains, Poland, Earth Planet. Sci. Lett., 15, 418-422, 1972.
Carlson, W. D.: Mechanism and kinetics of apatite fission track annealing, Am. Mineral., 75, 1120-1139, 1990.

Crowley, K. D., Cameron, M., and Schaefer, R. L.: Experimental studies of annealing of etched fission tracks in fluorapatite, Geochim. Cosmochim. Acta. 55, 1449-1465, 1991.

Csiky, G.: (1968): Latest results and perspectives of hydrocarbon prospecting in the Paleogene basin of Hungary, Földtani Közlöny, 98, 29-40, 1968.

Csontos, L.: Tertiary tectonic evolution of the Intra-Carpathian area: a review, Acta Vulcanologica, 7(2) 1-13, 1995.

Dallmeyer, R. D., Neubauer, F., Handler, R., Fritz, H., Müller, W., Pana, D., and Putis, M.: Tectonothermal evolution of the internal Alps and Carpathians: ${ }^{40} \mathrm{Ar} /{ }^{39} \mathrm{Ar}$ mineral and whole rock data, Ecl. Geol. Helv., 89, 203-277, 1966.

Decker, K.: Miocene tectonic at the Alpine-Carpathian junction and the evolution of the Vienna basin, Mitt. Ges. Geol. Bergbaustud. Österr., 41, 33-44, 1996.

Dodson, M. H.: Closure temperature in cooling geochronological and petrological systems, Contrib. Mineral. Petrol. 40, 259-274, 1973.

Donelick, R. A., Ketcham, R. A., and Carlson, W. D.: Variability of apatite fission-track annealing kinetics II: Crystallographic orientation effects, American Mineralogist, 84, 1224-1234, 1999.

Dövényi, P. and Horváth, F.: A review of temperature, thermal conductivity, and heat flow data from the Pannonian Basin, in: Royden, L. H. and Horváth, F. (Eds.): The Pannonian Basin - a Study in Basin Evolution, Amer. Assoc. Petr. Geol., Memoir 45, 235255, 1988.

Dunkl, I.: Latest milestones of the uplift story of the eastern margin of Eastern Alps: compilation of fission track results, Terra Abstract, 4, 18, 1992.

Dunkl, I.: Thermochronological investigation of drill cores, Unpubl. report, Laboratory for Geochemical Research, 36, Budapest, 1993.

Dunkl, I. and Demény, A.: Exhumation of the Rechnitz Window at the border of Eastern Alps and Pannonian basin during Neogene extension, Tectonophysics, 272, 197-211, 1997.

Dunkl, I., Árkai, P., Balogh, K., Csontos, L., and Nagy, G.: Thermal modelling based on apatite fission track dating: the uplift history of the Bükk Mts. (Inner Western Carpathians, Hungary), in Hungarian with Engl. abstr., Földtani Közlöny, 124, 1-24, Budapest, 1994.

Dunkl, I., Grasemann, B., and Frisch, W.: Thermal effects of exhumation of a metamorphic core complex on hanging wall synrift sediments - an example from the Rechnitz Window, Eastern Alps, Tectonophysics, 297, 31-50, 1998.

Ebner, F. and Sachsenhofer, R. F.: Paleogeography, subsidence and thermal history of the Neogene Styrian basin (Pannonian basin system, Austria), Tectonophysics, 242, 133-150, 1991.

Eder, N. and Neubauer, F.: On the edge of the extruding wedge: Neogene kinematics and geomorphology along the southern Niedere Tauern, Eastern Alps, Eclogae geol. Helv., 93, 81-92, 2000.

Exner, C.: Beitrag zur Kenntnis der jungen Hebung der östlichen Hohen Tauern, Mitt. Geogr. Ges. Wien, 91, 186-196, 1949.

Fleischer, R. L., Price, P. B., and Walker, R. M.: Nuclear tracks in solids; Principles and applications, University of California Press, Berkeley, 1975.

Flügel, H. W.: Steirisches Becken-Südburgenländische Schwelle; Geologische Karte des prätertiären Untergrundes 1:200000. Geol. B.-A. (Wien), 1988. 
Flügel, H. W. and Neubauer, F.: Geologische Karte der Steiermark 1:200 000. Mitt. Abt. Geol. und Paläont. Landesmuseum Joanneum, v. 45, 1984.

Fodor, L., Jelen, B., Márton, E., Skaberne, D., Car, J., and Vrabec, M.: Miocene-Pliocene tectonic evolution of the Slovenian Periadriatic fault: implications for Alpine-Carpathian extrusion models, Tectonics, 17, 690-708, 1998.

Fodor, L.: From transpression to transtension: Oligocene-Miocene structural evolution of the Vienna Basin and the East Alpine - Western Carpathian junction, Tectonophysics, 242, 151-182, 1995.

Fodor, L., Csontos, L., Bada, G., Györfy, I., and Benkovics, L.: Tertiary tectonic evolution of the Pannonian Basin system and neighbouring orogens; a new synthesis of paleostress data, in: Durand, B., Jolivet, L., Horváth, F., and Séranne, M. (Eds.): The Mediterranean basins: Tertiary extension within the Alpine orogen, Geological Society, London, Special Publication, 156, 295334, 1999.

Frank, W., Kralik, M., Scharbert, S., and Thöni, M.: Geochronological data from the Eastern Alps, in: Flügel, H. W. and Faupl, P. (Eds.): Geodynamics of the Eastern Alps, F. Deuticke, Wien, 272-281, 1987.

Frank, W., Lelkes-Felvári, Gy., and Dunkl, I.: Thermal history of Austroalpine basement rocks of the borehole Fertörákos-1004, Western Hungary, in: Dudich, E. and Lobitzer, H. (Eds.): Advances in Austrian-Hungarian Joint Geological Research, Budapest, 177-195, 1996.

Frey, M., Desmons, J., and Neubauer, F.: The new metamorphic maps of the Alps: Introduction, Schweiz, Mineral. Petrogr. Mitt., 79, 1-4, 1999.

Frisch, W., Kuhlemann, J., Dunkl, I., and Brügel, A.: Palinspastic reconstruction and topographic evolution of the Eastern Alps during late Tertiary tectonic extrusion, Tectonophysics, 297, 115, 1998.

Fuchs, W.: Grosstektonische Neuorientierung in den Ostalpen und Westkarpaten unter Einbeziehung plattentektonischer Gesichtspunkte, Jahrbuch der geologischen Bundesanstalt, 127, 571-631, 1985.

Fügenschuh, B., Seward, D., and Mancktelow, N.: Exhumation in a convergent orogen: the western Tauern window, Terra Nova, 9, 213-217, 1997

Fülöp, J.: Geology of Hungary, Paleozoic I, (in Hungarian), Hung. Geol. Inst., Budapest, 326, 1990.

Gallagher, K.: Monte Trax - a fission track thermal history modelling program for Macintosh, Manuscript - Software Manual, 30, 1993.

Gerner, P., Bada, G., Dövényi, P., Müller, P., Oncescu, C., Cloetingh, S. A.P.L., and Horváth, F.: Recent tectonic stress and crustal deformation in and around the Pannonian Basin: data and models, in: Durand, B., Jolivet, L., Horváth, F., and Séranne, M. (Eds.): The Mediterranean basins: Tertiary extension within the Alpine orogen, Geological Society, London, Special Publication, 156, 269-294, 1999.

Genser, J., van Wees, J. D., Cloetingh, S. A. P. L., and Neubauer, F.: Eastern Alpine tectono-metamorphic evolution: constraints from two-dimensional P-T-t modelling, Tectonics, 15, 584-604, 1996.

Gleadow, A. J. W., Duddy, I. R., and Lovering, J. F.: Fission track analysis: a new tool for the evaluation of thermal histories and hydrocarbon potential, Australian Petrol. Explor. Assoc. J., 23, 93-102, 1983.

GLOBE Task Team and others (Hastings, D. A., Dunbar, P. K., Elphingstone, G. M., Bootz, M., Murakami, H., Maruyama, H.,
Masaharu, H., Holland, P., Payne, J., Bryant, N. A., Logan, T. L., Muller, J.-P., Schreier, G., and MacDonald, J. S.) (Eds.): The Global Land One-kilometer Base Elevation (GLOBE) Digital Elevation Model, Version 1.0. National Oceanic and Atmospheric Administration, National Geophysical Data Center, Boulder, Digital data base on the World Wide Web (http://www. ngdc.noaa.gov/seg/topo/globe.shtml), 1999.

Grasemann, B. and Dunkl, I.: Modeling of the thermal structure during footwall uplift: constraints on the geometry of normal faulting (Rechnitz metamorphic core complex, Eastern Alps), Mitt. österreichische Geol. Ges. (submitted), 2002.

Grundmann, G. and Morteani, G.: The young uplift and thermal history of the Central Eastern Alps (Austria/Italy), evidence from apatite fission track ages, Jb. Geol. B.-A., 128, 197-216, 1985.

Hejl, E.: "Cold spots" during the Cenozoic evolution of the Eastern Alps, Tectonophysics, 272, 159-173, 1997.

Hejl, E. and Wagner, G.: Apatit-Spaltspurendaten zur thermischen Geschichte der Nördlichen Kalkalpen, der Flysch- und Molassezone, Jb. Geol. B.-A. Wien, 132, 191-212, 1989.

Hejl, E. and Wagner, G.: Spaltspuren in Apatit und Zirkon: Schlüssel zur Niedertemperatur- und Hebungsgeschichte der Alpen, Schweiz, Mineral. Petrogr. Mitt., 71, 63-71, 1991.

Horváth, F.: Phases of compression during the evolution of the Pannonian Basin and its bearing on hydrocarbon exploration, Marine and Petroleum Geology, 12, 837-844, 1995.

Horváth, F., Dövényi, P., and Laczó, I.: Geothermal effect of magmatism and its contribution to the maturation of organic matter in sedimentary basins, Lecture Notes in Earth Sciences, 5, 173193, 1986.

Horváth, F. and Cloetingh, S. A.P. L.: Stress-induced late-stage subsidence anomalies in the Pannonian basin, Tectonophysics, 266, 287-300, 1996.

Hunziker, J. C., Desmons, J., and Hurford, A. J.: Thirty-two years of geochronological work in the Central and Western Alps: a review on seven maps, Mémoires de Géologie (Lausanne), 13, 59, 1992.

Jámbor, Á.: Pannonian in the Transdanubian Central Mountains, (in Hungarian with English summary), Ann. Hung. Geol. Surv., 62, 259, 1980.

Jelen, B., Anicic, B., Brezigar, A., Buser, S., Cimerman, F., Drobne, K., Monostori, M., Kedves, M., Pavsic, J., and Skaberne, D.: Model of positional relationships for Upper Paleogene and Miocene strata in Slovenia, in: Montanari, A. (Ed.): IUGS-SOG Meeting Ancona, Abstracts and field trips, 71-72, 1992.

Ketcham, R. A., Donelick, R. A., and Donelick, M. B.: AFTSolve: A program for multi-kinetic modeling of apatite fission-track data, Geological Materials Research, October v 2nl, 1-32, 2000.

Král', J.: Fission track ages of apatites from some granitoid rocks in West Carpathians, Geol. Zb.-Geol. Carphathica, 28, 269-276, 1977.

Kuhlemann, J.: Post-collisional sediment budget of Circum-Alpine basins (Central-Europe), Mem. Sci. Geol. (Padova), 52, 1-91, 2000.

Laslett, G. M., Green, P. F., Duddy, I. R., and Gleadow, A. J. W.: Thermal annealing of fission tracks in apatite 2. A quantitative analysis, Chemical Geology, 65, 1-13, 1987.

Lelkes-Felvári, Gy., Sassi, F. P., and Visonà, D.: Pre-Alpine and Alpine developments of the Austridic basement in the Sopron area (Eastern Alps, Hungary), Rend. Soc. It. Mineral. Petrol., 39, 593-612, 1983.

Maluski, H., Rajlich, P., and Matte, $\mathrm{Ph} .:{ }^{40} \mathrm{Ar} /{ }^{39} \mathrm{Ar}$ dating of the 
Inner Carpathians Variscan basement and Alpine mylonitic overprinting, Tectonophysics, 223, 313-337, 1993.

Márton, E., Kuhlemann, J., Frisch, W., and Dunkl, I.: Miocene rotations in the Eastern Alps - Paleomagnetic results from intramontane basin sediments, Tectonophysics, 323, 163-182, 2000.

Müller, W., Dallmeyer, R. D., Neubauer, F., and Thöni, M.: Deformation-induced resetting of $\mathrm{Rb} / \mathrm{Sr}$ and ${ }^{40} \mathrm{Ar}-{ }^{39} \mathrm{Ar}$ mineral systems in a low-grade, polymetamorphic terrane (Eastern Alps, Austria), J. Geol. Soc. (London), 156, 261-278, 1999.

Neubauer, F., Dallmeyer, R. D., Dunkl, I., and Schirnik, D.: Late Cretaceous exhumation of the metamorphic Gleinalm dome, Eastern Alps: kinematics, cooling history and sedimentary response in a sinistral wrench corridor, Tectonophysics, 242, 7989, 1999.

Neubauer, F., Hoinkes, G., Sassi, F. P., Handler, R., Höck, V., Koller, F., and Frank, W.: Pre-Alpine metamorphism of the Eastern Alps, Schweiz, Mineral. Petrogr. Mitt., 79, 41-62, 1999.

Neubauer, F., Fritz, H., Genser, J., Kurz, W., Nemes, F., Wallbrecher, E., Wang, X., and Willingshofer, E.: Structural evolution within an extruding wedge: model and application to the Alpine-Pannonian system, in: Urai, J., Lehner, F., and van Zee, W. (Eds.): Aspects of tectonic faulting (Festschrift in Honour of Georg Mandl), Springer, 141-153, 2000.

Pahr, A.: Gelogische Karte der Republik Österreich, 1:50 000, Erläuterungen zu Blatt 137, Oberwart. Geologische Bundesanstalt, Wien, 47p, 1984.

Pécsi, M.: Geomorfológia és Domborzatminösítés (Geomorphology and relief evaluation), Hungarian Academy of Sciences, 220p, 1991.

Peresson, H. and Decker, K.: The Tertiary dynamics of the northern Eastern Alps (Austria); changing palaeostresses in a collisional plate boundary, Tectonophysics, 272, 125-157, 1997.

Ratschbacher, L., Behrmann, J. H., and Pahr, A.: Penninic windows at the eastern end of the Alps and their relation to the intraCarpathian basins, Tectonophysics, 172, 91-105, 1990.

Ratschbacher, L., Frisch, W., Linzer, H.-G., and Merle, O.: Lateral extrusion in the Eastern Alps, part 2. Structural analysis, Tectonics, 10, 257-271, 1991.

Reinecker, J., Dunkl, I., Székely, B., Kuhlemann, J., and Frisch, W.: Differential exhumation, vertical movements and the lateral extrusion in the eastern Eastern Alps, Abstract 4th Workshop on Alpine Geological Studies, Tübingen 21.-24.9.99. Tübinger Geowissenschaftliche Arbeiten (TGA) Reihe A, 52, 45-46, 1999.

Reinecker, J. and Lenhard, W. A.: Present-day stress field and deformation in eastern Austria, Int. Jour. Earth Sci., 88, 532- 550, 1999.

Royden, L., Horváth, F., and Burchfiel, B. C.: Transform faulting, extension and subduction in the Carpathian Pannonian region, Geol. Soc. Amer. Bull., 73, 717-725, 1982.

Royden, L. and Horváth, F. (Eds.): The Pannonian Basin - a Study in Basin Evolution, Amer. Assoc. Petr. Geol. Mem., 45, 394p, 1988.

Sacchi, M., Horváth, F., and Magyari, O.: Role of unconformitybounded units in the stratigraphy of the continental record: a case study from the Late Miocene of the western Pannonian Basin, Hungary, in: Durand, B., Jolivet, L., Horváth, F., and Séranne, M. (Eds.): The Mediterranean basins: Tertiary extension within the Alpine orogen, Geological Society, London, Special Publication, 156, 357-390, 1999.

Sachsenhofer, R. F.: Maturität im Steirischen Tertiärbecken, Erdöl Erdgas Kohle, 107, 12-17, 1991.
Sachsenhofer, R. F.: Coalification and thermal histories of Tertiary basins in relatation to late Alpidic evolution of the Eastern Alps, Geologische Rundschau, 81, 291-308, 1992.

Sachsenhofer, R. F.: Petroleum generation and migration in the Styrian Basin (Pannonian Basin system, Austria): an integrated geochemical and numerical modelling study, Marine and Petroleum Geology, 11, 684-701, 1994.

Sachsenhofer, R. F., Lankreijer, A., Cloetingh, S. A.P.L., and Ebner, R.: Subsidence analysis and quantitative modelling in the Styrian Basin (Pannonian Basin System, Austria), Tectonophysics, 272, 175-196, 1997.

Sachsenhofer, R. F., Dunkl, I., Hasenhüttl, Ch., and Jelen, B.: Miocene thermal history of the southwestern margin of the Styrian Basin: coalification and fission track data from the Pohorje/Kozjak area (Slovenia), Tectonophysics, 297, 17-29, 1998.

Sachsenhofer, R. F., Jelen, B., Hasenhüttl, Ch., Dunkl, I., and Rainer, T.: Thermal history of Tertiary basins in Slovenia (Alpine-Dinaride-Pannonian junction), Tectonophysics, 334, 77-99, 2001.

Sanders, C.: Tectonics and erosion - competitive forces in a compressive orogen. Unpubl. Ph. D. Thesis, Vrije Univ., Amsterdam, 204 p, 1998.

Staufenberg, H.: Apatite fission-track evidence for postmetamorphic uplift and cooling history of the Eastern Tauern Window and the surrounding Austroalpine (Central Eastern Alps, Austria), Jb. Geol. B.-A., 130, 571-586, 1987.

Stegena, L.: Geothermics, manuscript, Eötvös University, (in Hungarian), 1979.

Szabó, Cs.,Harangi, Sz., and Csontos, L.: Review of Neogene and Quaternary volcanism of the Carpathian-Pannonian region, Tectonophysics, 208, 243-256, 1992.

Tari, G.: Strike-slip origin of the Vatta-Maklár Trough, northeastern Hungary, Acta Geol. Hung., 31, 101-109, 1988.

Tari, G., Horváth, F., and Rumpler, J.: Styles of extension in the Pannonian Basin, Tectonophysics, 208, 203-219, 1992.

Tari, G., Dövényi, P., Dunkl, I., Horváth, F., Lenkey, L., Stefanescu, M., Szafián, P., and Tóth, T.: Lithospheric structure of the Pannonian basin derived from seismic, gravity and geothermal data, in: Durand, B., Jolivet, L., Horváth, F., and Séranne, M. (Eds.): The Mediterranean basins: Tertiary extension within the Alpine orogen, Geological Society, London, Special Publication, 156, 215-250, 1999.

Thiedig, F.: Verbreitung, Ausbildung und stratigraphische Einstufung neogener Rotlehme und Grobschotter in Ostkärnten (Österreich), Mitt. Geol.-Paläont. Inst. Univ. Hamburg, 39, $97-$ $116,1970$.

Tóth, T. and Horváth, F.: Evidence of Quaternary Tectonism in the area around Paks, Földtani Közlöny, Budapest, 129, 109-124, 1999.

Vida, R., Tóth, T., and Magyari, O.: (1998): Ultra-high resolution seismics on the Lake Balaton, Hungary; processing and interpretation, Annales Geophysicae, 16, Suppl. 1, p 167, 1998.

Villa, I. M.: Isotopic closure, Terra Nova, 10, 42-47, 1998.

Wagner, G. A.: Correction and interpretation of fission-rack ages, in: Jäger, E. and Hunziker, J. C. (Eds.): Lectures in isotope geology, Springer, Berlin, 170-177, 1979.

Wagner, G. A., Reimer, G. M., and Jäger, E.: Cooling ages derived by apatite fission track, mica $\mathrm{Rb}-\mathrm{Sr}$ and $\mathrm{K}-\mathrm{Ar}$ dating: the uplift and cooling history of the Central Alps, Mem. Ist. Geol. Univ. Padova, 30, 1-27, 1977.

Willett, S. D.: Modelling thermal annealing of fission tracks in apatite, in: Zentilli, M. and Reynolds, P. H.: Short course handbook 
on low temperature thermochronology, Mineralogical Association of Canada, 43-72, 1992.

Willingshofer, E.: Extension in collisional orogenic belts: the Late
Cretaceous evolution of the Alps and Carpathians. Unpubl. Ph. D. Thesis, Vrije Universiteit, Amsterdam, 146p., 1999. 